\title{
Boosting Higher Education in Africa through Shared Massive Open Online Courses (MOOCs)
}

\author{
Gérard Escher, Dimitrios Noukakis, and Patrick Aebischer
}

\begin{abstract}
Massive open online courses (MOOCs) have taken the world of higher education by storm. Ubiquitous use of tablets and smartphones, rapid increase of broadband penetration, and the coming-of-college-age of the 'digital native' generation have led many top universities to offer some of their courses to a wider audience online, free of charge. Millions of students are actively engaging. We present lessons learned after two years of experience with these new educational platforms and explore the opportunities and challenges of delivering MOOCs to students in Africa (and other developing regions) through a North-South partnership involving universities and teaching staff.
\end{abstract}

\section{Acknowledgements}

The authors would like to thank Patrick Jerman, Executive Director, and Pierre Dillenbourg, Academic Director of the Centre for Digital Education (CEDE) at École polytechnique fédérale de Lausanne (EPFL) for their helpful insights into the world of MOOCs and for providing EPFL data. We thank Sanna Fowler for help with editing the manuscript.

\section{Introduction}

Higher education in its present form is falling short of worldwide demand, currently estimated at 100 million potential students annually, primarily from emerging economies (Laurillard, 2014). By 2020 the population aged between 18 and 22 is expected to number 474 million (Lawton et al., 2013), with India and China accounting for 210 million of this cohort. Over the next decade, significant growth in enrolment in tertiary education is forecast,

(C) Graduate Institute of International and Development Studies, 2014 | DOI 10.1163/9789004281158_011 This is an open access chapter distributed under the terms of the Creative Commons Attribution- 
notably in China (37m), India (28m), the USA $(20 \mathrm{~m})$, Brazil $(9 \mathrm{~m})$, but also in Nigeria $(1.4 \mathrm{~m})$, Turkey $(0.7 \mathrm{~m})$ and Ethiopia $(0.6 \mathrm{~m})$ (British Council, 2012). Given that only about 2 per cent of students in higher education globally study in countries other than their own (Lawton et al., 2014), current levels of student mobility across borders are not expected to meet the growing demand. Furthermore, building brick-and-mortar universities to satisfy demand is also likely to pose a major challenge for many countries. For instance, between 2009 and 2011 alone, China had to build 426 new higher education institutions, for a total of 2,049 universities. Access to higher education for all-in the words of former UK Prime Minister, Gordon Brown, 'the global ladder of opportunity for education'-is threatened by a huge increase in demand for higher education.

Globalisation of the education sector is being driven by the rapid spread of Internet access. As of 2013, 77 per cent of the industrialised world and 31 per cent of the global South had Internet access. The growth of mobile connectivity, particularly in the developing world, has brought online content and interaction to a global audience (UNESCO, 2013). By January 2014, the global population had risen to just over 7 billion, of whom 2.5 billion ( 35 per cent) were Internet users, and 1.9 billion were active social network users ( 26 per cent penetration). Across the world, current mobile subscription penetration is 93 per cent (with 6.6 billion mobile subscriptions) (We Are Social, 2014). Africa has an Internet penetration of 18 per cent, and a social network penetration of 7 per cent. However, mobile phone penetration is currently an impressive 67 per cent. The most important regional differences today are found in levels of broadband penetration: 55 per cent in Europe, 7 per cent in Africa (primarily mobile 'smartphone' broadband subscriptions), and 4 per cent in India (We Are Social, 2014).

Online education is driven by both student demographics and Internet penetration. Although 'distance learning' has been a feature of higher education since the 1960s (starting with the Open University in the UK), the path of online education is littered with corpses (Lawton and Katsomitros, 2012). For instance, investments of tens of millions of dollars were unable to prevent the collapse of NYOnline (New York University platform for continuing education) in 2001. Similarly, Fathom, a 2003 joint for-profit e-learning portal of Columbia University, the London School of Economics and others failed to survive, as did AllLearn, a not-for-profit collaboration between Yale, Oxford and Stanford, in 2006 (Haggard et al., 2013). Yet, despite these successive failures, MOOCs emerged. 
Two sets of factors have contributed to the rapid rise of MOOCs (Aebischer and Escher, 2013). First, technology has matured with widespread use of notebooks, tablets and smartphones, massive broadband penetration and easy cloud storage of data. Second, social factors too have been decisive: notably the coming-of-age of the 'digital native' generation that has now reached university age and with it the all-pervasive use of digital social networks for personal communication. Added to this, MOOCs saw the light of day within an entrepreneurial context, the 'Silicon Valley mentality'; finally, world-class universities were involved from the start. Unlike their online educational predecessors, the costs of MOOCs are borne not by students, but rather by institutions. MOOCs are open to everyone, they are synchronised-they follow a set timetable and deadlines, which enables social learning and interaction (crowd sourcing, ${ }^{1}$ peer grading and discussion forums) - and are personalised (Aebischer and Escher, 2013).

Several world-class universities, including École polytechnique fédérale de Lausanne (EPFL), have recognised the benefits of MOOCs in terms of increased visibility and reputation and have rapidly begun to offer them. MOOCs shift the focus towards high-quality teaching, resulting in higher levels of motivation and ultimately enhanced teaching both on and off campus. MOOCs also enable outreach to partner institutions in Africa and elsewhere. MOOCs have truly taken on a life of their own: since September 2012, some 400,000 students have enrolled in the courses offered by EPFL.

'MOOCs hyped, humbled, but hardy' (Bacon, 2013), is an accurate description of the MOOCs phenomenon. Launched in April 2012, within just four months Coursera, the leading MOOCs platform, had over 1 million students. In 2013, this had risen to 5.2 million users. By February 2014, the three biggest MOOC providers had 7.1 million (Coursera), 2.2 million (edX) and 1.6 million (Udacity) students respectively. ${ }^{2}$ The hype, however, has not gone unnoticed: only about 10 per cent of registrants complete a course. For this reason, perhaps, the number of courses and participating universities (numbers that are steadily

1 Crowdsourcing is the practice of obtaining services, goods, or content by soliciting contributions from a large group of people, and especially from an online community (see for instance Brabham, 2013).

2 The websites of the main MOOCs providers are https://www.coursera.org/, https://www.edx .org/ and https://www.udacity.com/ (accessed on 14 May 2014). 
increasing) provides a better metric of the success of MOOCs than the number of registrants, which counts both one-time video-watchers and students who complete all exercises. As of February 2014, Coursera offered 603 courses from 108 universities, while edX offered 140 courses from 31 universities.

MOOCs have been scrutinised extensively ( for a recent review of the literature, see Haggard et al., 2013). As early adopters of the platform, we at EPFL believe that 'MOOCs initiate a Copernican shift' (Pierre Dillenbourg, ${ }^{3}$ personal communication, 2014). 'If students can watch the video of the course at their own pace before the exercise session, this session will progressively become the most important learning event.'

MOOCs were initially proposed as individualised learning tools, since each student could watch the videotaped courses and do the quizzes and exercises at leisure. Our students appreciate the quality of the courses and the flexibility to replay the course in their own time; however they have also stressed the importance of social interaction.

The motivations underlying a student's decision to take a MOOC are many and varied. About half of MOOC students surveyed reported that they had enrolled out of 'curiosity, just for fun', while 43.9 per cent said they had enrolled to 'gain skills to do my job better' (Christensen et al., 2013). Evidence from several universities suggests that well over 60 per cent of those who register for MOOCs already have university degrees (Christensen et al., 2013). At EPFL, the average age of MOOCs students was 26 years, 34 per cent had a Bachelor's degree, while 31 per cent had a Master's degree; about half of students wanted a certificate, and 80 per cent cited career advancement as a reason for enrolling in a MOOC (unpublished EPFL data).

Despite their popularity, MOOCs remain primarily the preserve of the privileged and are currently failing to reach the disadvantaged. A recent University of Pennsylvania survey of 35,000 students who had undertaken at least one assignment of a course showed that of participants from developing countries, 80 per cent already had a college degree (Emanuel, 2013). Based on Coursera numbers from April 2013, only 2 per cent of registrants were from Africa (UNESCO, 2013). Better access to technology globally will be necessary before

3 Academic director of the EPFL Centre for Digital Education and head of the CHILI (Computer-Human Interaction for Learning and Instruction Lab). 
MOOCs can live up to their promise to reach underprivileged students, in and outside universities (Emanuel, 2013).

It has long been recognised (e.g. the Open University experience in UK) that students of distance-learning often struggle to complete a course if left to their own devices; MOOCs will have to pay close attention to this if they are to reach underprepared college students. Nevertheless, MOOCs have once again raised awareness among universities of the value of affordability and access, and have brought the conversation back to teaching and learning.

MOOCs allow faculty to 'flip the classroom', i.e. teach the usual ex-cathedra class online while concentrating on problems, exercises and discussions in class. This could conceivably be applied to universities across whole sectors (Lawton and Katsomitros, 2012): if introductory lectures were provided online en masse to a consortium of subscribing institutions, it would free up resources to focus on hands-on seminars and laboratory-based teaching and learning. In the future, MOOC technology could become widely used by faculty members to break down their existing residential courses into modules- the 'textbook function' of MOOCs. However, there is a risk that this 'unbundling' of courses could ultimately result in universities moving away from strict 3- or 4-year curricula (Harvard Magazine, 2013), with students building a personal education path by picking from a vast array of individual modules. The momentum created by MOOCs may also result in a new 'packaging': to date, MOOCs have been delivered as individual courses, however, they may in future aggregate into full and later, accredited programmes. For instance, Udacity has already created a USD 6,000 Master's degree in computer science in partnership with AT\&T and Georgia Tech. ${ }^{4}$ Finally, different universities using common lectures, complemented by seminars and exercises unique to each location, are certain to be part of the landscape in 2020 (Lawton et al., 2013); this will be of great relevance in the deployment of MOOCs in Africa since both partners from the North and the South will be able to contribute to the content of the course.

The number of MOOCs providers is likely to multiply. In addition to the 'Big Three', a number of providers or platforms have already been created. The most recent include France Université Numérique (FUN, financed by the French

4 On this partnership with Georgia Tech and AT\&T, see the Udacity webpage 'Online Master of Science in Computer Science': https://www.udacity.com/georgia-tech (accessed on 7 May 2014). 
Ministry of Education with EUR 20 million), ${ }^{5}$ and the Queen Rania MOOC Portal of the Arab World, EDRAAK. Both FUN and EDRAAK are powered by the open edX platform. Others include FutureLearn (UK), Iversity (Germany), Miriade (Spain), Rwaq (Saudi Arabia) and Xuetang (China). Similarly, Pan European platforms have also been established (the OpenUpEd initiative), as have Francophone portals (Ocean). ${ }^{6}$ Over the coming years, intense competition between different providers (or even countries) may drive the development of MOOCs, with important impacts on the MOOCs' economic model (will they remain cost-free to students?), university intellectual property (this is about student data and course content, with the interplay of the university, the professor and the MOOC provider).

Finally, while MOOCs have been developed with the typical 'can do' spirit of Silicon Valley, their sustainability will depend on the regulatory environment. In keeping with PCAST, the (US) President's Council of Advisers on Science and Technology (2013), we suggest three strategies: (1) let market forces decide which innovations in online teaching and learning are best; (2) encourage accrediting bodies to be flexible in response to educational innovation, and (3) support research and the sharing of results on effective teaching and learning.

Over a period of just 15 years, the number of higher education students in Africa increased by an average of 16 per cent per year, climbing from 2.7 million in 1991 to 9.3 million in 2006, while the level of public funding grew only at 6 per cent annually. Despite dramatic growth, only 6 per cent of collegeage students in Africa are enrolled in higher education, compared to 20-40 per cent in most developing countries and 72 per cent in North America and Western Europe (World Bank, 2010).

A World Bank review of French-speaking Africa, meanwhile, suggests that expansion of higher education has been impressive, with enrolment rates doubling between 1991 and 2004 (Brossard and Foko, 2008). However, average higher education coverage remains low, as only an estimated 3 per cent of individuals in Francophone Africa currently have access to higher education

5 http://www.france-universite-numerique.fr/nouvelles-mesures-pour-developper-les-moocs .html (accessed on 14 May 2014).

6 See the websites of these platforms, amongst others, FUN: http://www.france-universitenumerique.fr/; EDRAAK: https://www.edraak.org/; FutureLearn: https://www.futurelearn .com/; OpenUpEd: http://www.openuped.eu/ (accessed on 7 May 2014). 
(2008 figures). The World Bank study shows that public expenditure per student is high in most of the countries studied, with important social (student assistance services) expenditure, and high administrative costs. The student population in French-speaking Africa is expected to grow from 800,000 in 2004 to approximately 2 million in 2015, making the development of higher education financially unsustainable. In a sample containing 18 of the 21 countries in French-speaking Africa for which data are available, the funding gap for current expenditure on public higher education over the 2004-15 period was about USD 3.3 billion (in 2004 USD). Yet the expansion of higher education in Francophone Africa corresponds to rising social demand. The World Bank report suggests that this demand will continue to grow over the coming decade due to the expansion in secondary education, the increase in universal primary completion (UPC) rates, and high levels of private sector profitability-28 per cent for one year of higher studies in French-speaking Africa versus only 19 per cent worldwide (Brossard and Foko, 2008).

\section{The Information and Communication Technologies Revolution in Africa}

The International Telecommunication Union (ITU) estimates that 16 per cent of sub-Saharan Africans (about 140 million people) are using the Internet today and that only 6.7 per cent of households have access - mainly in urban centres. Even in Kenya, where an undersea cable from the United Arab Emirates (UAE) has been operating since 2009, 72 per cent of the population lack Internet access (yet only 11 per cent lack telephone access). Africa's unmet demand for telecoms, therefore, remains very high (Lawton and Burrows, 2013). Online and distance provision can reduce the cost of education while at the same time increasing access. Although there is limited ICT infrastructure in Africa, it is improving: the expanding undersea fibre optic cable network around the continent is rapidly increasing the number of living rooms from which MOOCs can be accessed (Lawton and Burrows, 2013).

As in many other developing countries, African states have relied heavily on foreign loans for their development, mainly from the International Monetary Fund (IMF) (Samoff and Caroll, 2003). As a result, in the 1980s most states adopted structural adjustment programmes and their agendas, with their emphasis on deregulation and privatisation of services to promote economic growth. Meanwhile, fiscal crises and budget constraints of the 1970s resulted in chronic underfunding of the public sector in general and the education sector in particular (Mkandawire, 2005). The resources available were targeted at the 
expansion of primary education, which was seen by the international development community as a better use of funds, yielding more beneficial returns for state development. Even the Poverty Reduction Strategy Papers (PRSP), which most African states have adopted in recent years, exclusively identify primary education as key to development (Samoff and Caroll, 2003). As a result, higher education has not been given priority in most states. According to David Bloom, 'the international development community has encouraged African governments' relative neglect of higher education. For example, from 1985 to 1989,17 per cent of the World Bank's worldwide education-sector spending was on higher education. But from 1995 to 1999, the proportion allotted to higher education declined to just 7 per cent' (Bloom et al., 2006).

This failure to prioritise higher education in Africa has had a considerable impact on its current state. Lack of funds has directly affected institutional budgets, resulting in imposition of tuition fees and inadequate equipment (Varghese, 2004). As a result, only privileged groups are able to assume the financial burden and therefore benefit from higher education institutions, effectively limiting access to an exclusive section of the population. Another result of underfunding in higher education is the state of independent research and publication. Most institutions emphasise teaching and do not allocate sufficient resources to funding research (Varghese, 2004). This affects the academic discourse and the quality of lecturers. However, the neglect of educational services has also facilitated the emergence of private institutions to compensate for the absence of quality public education. This private sector is well funded and manages to provide an exclusive group with a good education (Mkandawire, 2005).

Private sector institutions charge higher tuition fees and are able to pay better salaries to their employees. Education therefore often becomes a two-speed system consisting of an underfunded, inadequate public sector on the one hand and a fragmented private sector of superior quality, on the other hand (Bloom et al., 2006).

In the developed world, MOOCs are expected to promote the idea of lifelong learning and encourage new interactive teaching methods and exchange of views among students (Lane, 2013). Whether MOOCs will revolutionise education entirely or turn out to be an improved kind of existing e-learning method remains to be seen; their potential for education in developing countries is in our view real, but must be carefully monitored. The most apparent advantage 
addresses the lack of resources at universities. Accommodating high-quality MOOCs from leading universities in the existing curricula of African institutions can greatly improve the quality of courses. Moreover, MOOCs not only educate students, but also help lecturers to update their knowledge (Liyanagunawardena et al., 2013). This is especially true in technical subjects such as engineering, where the lack of state-of-the-art equipment and highly skilled staff greatly affects the proficiency of students; here, MOOCs have the potential to improve higher education (World Bank, 2013). But MOOCs are educational tools created in a developed context. Their approach to teaching and learning might differ greatly from African forms of education, which are largely copied from older European models. As an example, ex-cathedra teaching still remains the dominant form of lecture in African universities. It remains to be seen how MOOCs, with their innovative, interactive structure will fit in the African context.

As MOOCs are accessible to anyone with a working Internet connection, they may reach a much greater pool of interested learners outside higher education institutions (Liyanagunawardena et al., 2013). MOOCs have the potential to overcome the financial and infrastructural barriers that deny many people access to higher education. However, there are serious questions about the implementation of MOOCs in developing countries. While MOOCs are theoretically available to everyone, they still require a certain level of familiarity with technology (Younous, 2012). This greatly limits the pool of potential users, as Internet connections and tech-savviness become rare as distance from urban areas increases (Liyanagunawardena et al., 2013).

For the African Virtual University (AVU), ${ }^{7}$ the MOOC concept is appealing and has great potential. However, it is not without its limitations. In addition to technical challenges, MOOCs focus on courses, not on programmes and to date have no formal accreditation procedure. MOOCs should, according to AVU, morph into full and accredited massive open online programmes (MOOPs). AVU is currently conducting a feasibility study. MOOCs can offer a substitute for the textbook, especially for technical courses, and could therefore fit in with ongoing efforts by AVU to provide open education resources in which over 200 textbooks in English, French and Portuguese are available online free of charge.

7 Pan-African intergovernmental organisation, initially launched in Washington in 1997 as a World Bank project and later transferred to Kenya in 2002. Its mandate is to increase access to higher education and training through the use of information and communication technologies, see www.avu.org (accessed on 8 May 2014). 
A few projects have sought to implement MOOCs in Africa. The World Bank's New Economy Skills for Africa Program-Information and Communication Technologies (NESAP-ICT), launched in 2008, aims to improve the IT skills of Tanzanian graduates to meet the demand of emerging markets (World Bank, 2008). The NESAP-ICT programme offers a customised curriculum tailored to the needs of Tanzanian private sector employers. By combining existing courses and MOOCs from high-profile universities, NESAP-ICT guarantees the provision of top-quality education. Furthermore, private sector employers collaborate with the scheme to validate the relevance of its content as well as improve employment opportunities by offering internships to advanced students. In a way, the NESAP-ICT programme designs education according to the needs of the market and encourages closer collaboration between teaching institutions and employers.

The Kepler project in Rwanda, launched in 2013, takes an even more innovative approach. While pursuing similar goals to the NESAP-ICT programme, the Kepler scheme almost totally foregoes any kind of collaboration with existing educational institutions. Instead, the programme, built independently by a small community in Kigali, provides a campus-like environment in which students live together for the duration of the course and are assisted by qualified staff. Using MOOCs from leading universities, a customised degree course was developed to meet the needs of the Rwandan market (O’Neil, 2013). Just like the World Bank scheme, Kepler works in close consultation with the Rwandan private sector to identify the skills needed by graduates. During the four-year course, students have the opportunity to choose internships with potential employers and develop employment-specific skills (Kepler, 2013).

A few universities have embraced MOOCs' development as a way to enhance their own educational programmes, but also as a means to foster academic cooperation with other parts of the world and in particular with emerging economies. As an instigator of the RESCIF network, ${ }^{8}$ EPFL was in an ideal position to launch a large-scale initiative on higher education in Africa and emerging economies. The programme dubbed 'MOOCs for Africa and future

8 RESCIF (Réseau d'excellence des sciences de l'ingénieur de la Francophonie) is a Francophone network of science and technology universities. See http://www.rescif.net (accessed on 7 May 2014). 
emerging economies' was launched in spring 2013 and has since received support from the Swiss Agency for Development and Cooperation (SDC) as well as private donors.

In this programme, partners from the North develop MOOCs and work with faculty from African partners to integrate courses into local curricula. Alternatively, teaching staff from Northern and African universities work together to co-develop MOOCs. In both cases, faculty members from African universities spend a few weeks with their Northern counterparts to become acquainted with the technology, design the courses and subsequently record the lectures.

The EPFL-MOOCs collaboration in Africa seeks to create an alliance for higher education between institutions from the North and the South around a common MOOCs programme. In particular, it seeks to educate a generation of graduates so that they are able to make informed choices about technologies in Africa and emerging economies over the next decade; educate young professionals on technical disciplines in line with the needs of the local economy; work with universities from the South to build capacity to deliver up-to-date education; and reach a wider public, which traditionally does not have access to higher education courses (EPFL, 2012).

For MOOCs to reach their full potential in developing countries, several technological, cultural and administrative challenges will need to be addressed. One challenge rests with the fact that access to video-intensive online courses is dependent on IT hardware that comes with high acquisition costs. In addition, access to connected terminals is still limited in many universities, and insufficient connection bandwidth is frequent. These IT costs must be balanced with the expected economies of scale that MOOCs might bring to universities: no large lecture halls, lower course production costs from sharing among several partners. The often limited number of faculty members in African universities makes it difficult to allocate resources to new online education projects; MOOCs could be useful for building teaching capacity and increasing student numbers. Administrative hurdles, notably the necessary accreditation of courses at the national level and the validation of credits and universities, will hopefully be overcome by rectors and presidents of universities in the South, who see this project as an opportunity to build capacity and, at the same time, extend their academic ties with the North. Finally, even if access to courses from excellent universities is a powerful incentive for students, their acceptance of courses designed and delivered by instructors from the North may not be easy; the involvement of local teaching staff-something that is planned—will be important. 
MOOCs could be targeted at all those citizens wishing to further educate themselves. Key stakeholders and groups targeted by the 'MOOCs in Africa' initiative might include, but are not limited to:

a) Universities: Institutions of higher education, and for EPFL and partners, particularly those using French as a teaching language.

b) Students: Students following undergraduate and graduate programmes at partner academic institutions.

c) Professionals: Those working in the secondary or tertiary sector, or as independents, wishing to acquire further knowledge and a certification of professional value (continuing technical education).

d) Citizens: All those wishing to gain advanced-level education for their own personal development, without necessarily seeking a professional certification.

Table 10.1 summarises the potential added value for the different categories of students enrolled in MOOCs.

TABLE 10.1 Reaching African students and professionals who are using MOOCs

\begin{tabular}{|c|c|c|c|}
\hline Students & $\begin{array}{l}\text { In university } \\
\text { curriculum? }\end{array}$ & Rewards/Incentives & Expected outcome \\
\hline $\begin{array}{l}\text { Students with a first } \\
\text { degree (BSc, MSc and } \\
\text { Eng.) who could not } \\
\text { pursue graduate studies }\end{array}$ & No & $\begin{array}{l}\text { Access to scientific } \\
\text { literature, intern- } \\
\text { ships in Western } \\
\text { labs }\end{array}$ & $\begin{array}{l}\text { Stimulate technology- } \\
\text { oriented } \\
\text { entrepreneurship }\end{array}$ \\
\hline $\begin{array}{l}\text { Enrolled undergraduate } \\
\text { and graduate students }\end{array}$ & Yes & $\begin{array}{l}\text { Better and more } \\
\text { complete } \\
\text { education }\end{array}$ & $\begin{array}{l}\text { Diploma with greater } \\
\text { prestige }\end{array}$ \\
\hline $\begin{array}{l}\text { Professionals seeking } \\
\text { post-graduate or } \\
\text { continuing education }\end{array}$ & Yes & $\begin{array}{l}\text { Enhanced career } \\
\text { prospects }\end{array}$ & $\begin{array}{l}\text { Certificate, diploma } \\
\text { with professional } \\
\text { value }\end{array}$ \\
\hline
\end{tabular}

SOURCE: AUTHORS. 
Universities in Africa and many emerging economies lack qualified instructors. Too often, teaching staff do not have PhDs. Offering well-structured online courses from leading academics (in the form of MOOCs) represents a unique opportunity to help local faculty update their courses and connect with researchers/instructors from the North. In addition, MOOCs will enable them to present students with courses that are on a par with those delivered by world-class universities.

There are not enough specialised courses at the Master and post-graduate levels that address technological, financial and cultural challenges in Africa, while existing ones are often outdated. By offering MOOCs co-developed by academics from the North and the South, EPFL aims to provide the necessary know-how and logistical support to design graduate courses of direct relevance to developing countries and to focus on themes that are in line with global issues (water, energy, health, urban planning) and that need to be addressed by the North and the South. Finally, MOOCs will provide a platform for long-term partnerships between academics from the North and the South.

'Massification' of higher education in emerging economies is a major issue. Booming demographics coupled with chronic underfunding create serious capacity problems. The advent of MOOCs is part of the solution as it has the potential to replace some of the ex-cathedra lectures and, as a consequence, increase the capacity of local instructors. Integrating MOOCs in the local curricula in emerging economies will, on the one hand, increase the teaching capacity of local universities, while freeing up local instructors for more and better face-to-face interactions with the students; on the other hand, it will avoid duplicating courses and the necessity to build real-estate capacity (large lecture halls), especially for undergraduate courses (1st and 2nd year) in basic, natural and computer sciences.

French-speaking MOOCs have the potential to reach a large population. As of 2010, 180 million people used French to communicate or as a teaching language; of these, over 115 million were in Africa. The number of universities using French (fully or partially) as a medium of instruction in Africa is estimated to be about 269 (the Agence universitaire de la Francophonie (AUF), the higher education and research network of Francophone universities, has 782 members). Among the RESCIF network, eight universities from developing countries represent a community of 72,000 students and 5,500 academic staff, while those from developed countries represent 71,000 students and 8,500 
academic staff. ${ }^{9}$ In most emerging economies, access to graduate education is restricted to the privileged few. Options for access to quality courses are rather limited and often include a long stay in the North. Some students from Frenchspeaking Africa typically undertake graduate studies in France, Belgium or Canada, something that is not possible for many. As a result, there is a wide base of bright graduates (mainly Bachelors) who have entered professional life and for whom formal continuing education is either unaffordable or inaccessible. MOOCs represent a real opportunity for all those who have the educational background and intellect and are looking to further educate themselves (self-learning approach). For this to happen in Africa several challenges need to be overcome: first, improving Internet connectivity (access and bandwidth) in households and through wireless devices (3G and 4G); second, reducing costs of IT hardware (desktops, laptops, tablets) by favouring parallel imports to Africa so as to shake up the existing cartels that artificially inflate prices.

\section{MOOCs as Instruments of Cooperation and Coordination}

We have made use of the existence of the RESCIF network to develop and distribute MOOCs. In this model, universities from developed countries of the network, including EPFL, take the lead in developing a series of state-of-theart undergraduate MOOCs in French, and help faculty from the South integrate them into local curricula. They also liaise with Southern partners to co-develop specialised courses for graduate or continuing education. In turn, universities in the network from developing countries take actions to optimise the dissemination of the MOOCs across their campuses, integrate MOOCs-in their original form, or adapted - into their curricula, and participate in the codevelopment of specialised courses and their local promotion.

Managing such a large-scale project within a network of 14 universities and several external partners requires tight coordination. Table 10.2 lists the internal and external stakeholders identified thus far and their fields of interest/action.

Since the launch of the 'MOOCs for Africa and future emerging economies' initiative in Spring 2013, several milestones have been reached, and most importantly, several key stakeholders have confirmed their support by committing

9 See http://rescif.org (accessed on 7 May 2014). 
TABLE 10.2 Internal and external stakeholders of a MOOCs programme

\begin{tabular}{|c|c|c|}
\hline Stakeholders & Interest/Action & Project outcome \\
\hline University management & $\begin{array}{l}\text { Project promotion } \\
\text { Provision of HR and funds } \\
\text { Academic planning }\end{array}$ & $\begin{array}{l}\text { MOOCs implemented as } \\
\text { part of the educational offer }\end{array}$ \\
\hline Faculty members & $\begin{array}{l}\text { Development and use of } \\
\text { MOOCs }\end{array}$ & $\begin{array}{l}\text { High-quality educational } \\
\text { content as MOOCs }\end{array}$ \\
\hline Students & $\begin{array}{l}\text { Use of MOOCs } \\
\text { Feedback on educational } \\
\text { experience }\end{array}$ & $\begin{array}{l}\text { Improvement of skills and } \\
\text { competencies }\end{array}$ \\
\hline Ministries of Education & $\begin{array}{l}\text { Legal and regulatory } \\
\text { framework for the }\end{array}$ & $\begin{array}{l}\text { MOOCs adopted as part of } \\
\text { the instruction medium }\end{array}$ \\
\hline $\begin{array}{l}\text { Quality assurance and } \\
\text { accreditation agencies }\end{array}$ & integration of MOOCs & in $\mathrm{HE}$ \\
\hline $\begin{array}{l}\text { International funding } \\
\text { and aid agencies }\end{array}$ & $\begin{array}{l}\text { Financial and logistical } \\
\text { support for the } \\
\text { dissemination of }\end{array}$ & $\begin{array}{l}\text { Funding Internet } \\
\text { access points } \\
\text { Synergies and integration }\end{array}$ \\
\hline $\begin{array}{l}\text { International and regional } \\
\text { academic networks }\end{array}$ & $\begin{array}{l}\text { MOOCs at the local } \\
\text { level }\end{array}$ & $\begin{array}{l}\text { with complementary } \\
\text { actions }\end{array}$ \\
\hline $\begin{array}{l}\text { Private and institutional } \\
\text { donors }\end{array}$ & $\begin{array}{l}\text { Financial support for the } \\
\text { development and dissemi- } \\
\text { nation of MOOCs }\end{array}$ & $\begin{array}{l}\text { Funding } \\
\text { Promotion of the concept }\end{array}$ \\
\hline $\begin{array}{l}\text { NGOs with strong } \\
\text { presence in Africa }\end{array}$ & $\begin{array}{l}\text { Lobby telecom operators } \\
\text { and IT hardware } \\
\text { distributors }\end{array}$ & $\begin{array}{l}\text { Access to high bandwidth } \\
\text { fixed and mobile Internet } \\
\text { Access to low-cost IT } \\
\text { hardware }\end{array}$ \\
\hline Telecom operators & $\begin{array}{l}\text { Association with a high } \\
\text { visibility, high impact }\end{array}$ & $\begin{array}{l}\text { Branding } \\
\text { Marketing action }\end{array}$ \\
\hline IT hardware distributors & project & User data \\
\hline Citizens & $\begin{array}{l}\text { Access to further/continu- } \\
\text { ing education }\end{array}$ & $\begin{array}{l}\text { Competencies with } \\
\text { professional value }\end{array}$ \\
\hline
\end{tabular}


either financial, human or material resources. Early results are encouraging. In 2013, 8,573 African participants took part in six French-language MOOCs and while seven English-language MOOCs attracted 4,500 participants. Among these 13,073 participants, 22 per cent were active participants (who submitted assignments), 53 per cent were visitors (who watched videos) and 25 per cent were inactive.

Morocco is the country in Africa that features most connections to EPFL MOOCs ( $\mathrm{N}=3,705$ participants). In West, North and Middle Africa ( $\mathrm{N}=11,325)$, most participants take French-language courses. In south and East Africa $(\mathrm{N}=1,748)$ participants follow English-language courses (see Figure 10.1). Since September 2013, five MOOCs produced by EPFL and delivered in French via Coursera have been followed and documented by African universities; three of those, Initiation à la programmation JAVA, Comprendre les microcontrôleurs

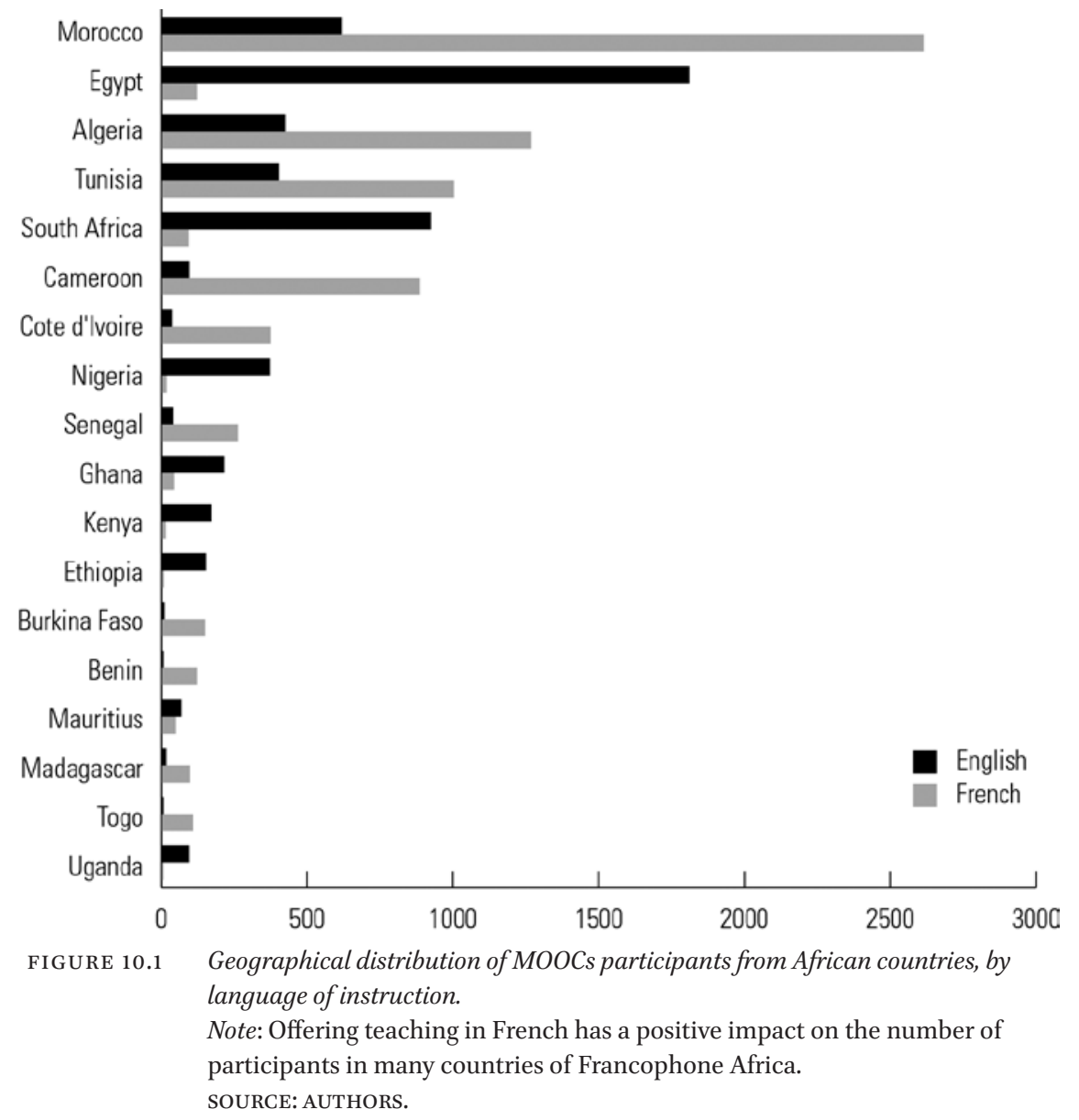


and La ville africaine: de la planification stratégique à l'aménagement urbain, were integrated into local curricula, designed to run with a network of local correspondents and involving hands-on laboratories and fieldwork. The first educational outcomes are currently being analysed.

Science Policy Aspects: MOOCs are considered a significant lever for development by many nations. EPFL has teamed up with the Swiss Agency for Development and Cooperation (SDC); similarly, Coursera is teaming up with the US State Department to set up 'learning hubs' in developing countries to accompany the use of MOOCs. Recently the US State Department declared MOOCs to be a service and banned students from countries under economic sanctions (Iran, Cuba, Sudan) from Coursera. These difficulties paradoxically pave the way for European platforms unhindered by these political considerations.

More and better research is needed: MOOCs are clearly in their infancy. While we are witnessing a non-reversible evolution of educational practices, we also know that the MOOC format will evolve; the name 'MOOC' may even disappear. The diversity of online education will inevitably be as broad as the diversity of education/training needs, and good study design is essential in this high-throughput education. There is no magic recipe for education; an ambitious educational project always encounters difficulties, which should not be a barrier to implementation.

The end of school? The radical intellectual Ivan Illich wrote in Deschooling Society (1971), 'A good educational system should have three purposes: it should provide all who want to learn with access to available resources at any time in their lives; empower all who want to share what they know to find those who want to learn it from them; and, finally, furnish all who want to present an issue to the public with the opportunity to make their challenge known.' MOOCs are getting close to this ideal of student empowerment. According to mathematician blogger Jo Boaler, 'A high-quality, innovative MOOC by someone who really knows what they are talking about is going to be better than low-quality face-to-face teaching' (Stanford, 2013). MOOCs will contribute to blurring the boundaries between universities and other units of knowledge dissemination, and will in the end shift the focus from institutions to a learning ecosystem' (Harvard Magazine, 2013). This 'global classroom' (Koller, 2013) will give people the opportunity to learn without limitations imposed by physical or socioeconomic constraints; and will offer schools and instructors around the world 
the ability to transcend boundaries to bring high-quality education to their students.

\section{References}

Aebischer, P. and G. Escher (2013) 'Can the IT revolution lead to a rebirth of world-class European universities?' in Weber, L.E. and J.J. Duderstadt (eds.) Preparing Universities for an Era of Change, Glion Colloquium Series No. 8 (London: Economica).

Bacon, J. (2013) 'MOOCs: Hyped, Humbled, Hardy', Bacon's Rebellion, 11 December, http://www.baconsrebellion.com/2013/12/moocs-hyped-humbled-hardy.html (accessed on 2 February 2014).

Bloom, D., D. Canning and K. Chan (2006) Higher Education and Economic Development in Africa (Washington, D.C.: World Bank).

Brabham, D.C. (2013) Crowdsourcing (Cambridge: The MIT Press).

British Council (2012) The Shape of Things to Come: Higher Education Global Trends and Emerging Opportunities to 2020, http://www.britishcouncil.org/sites/britishcouncil .uk2/files/the_shape_of_things_to_come_2.pdf (accessed on 7 May 2014).

Brossard, M. and B. Foko (2008) Costs and Financing of Higher Education in Francophone Africa (Washington, D.C.: World Bank), https://openknowledge.worldbank.org/ handle/10986/6449 (accessed on 7 May 2014).

Christensen, G., A. Steinmetz, B. Alcorn, A. Bennett, D. Woods and E.J. Emanuel (2013) The MOOC Phenomenon: Who Takes Massive Open Online Courses and Why? (Rochester, NY: Social Science Research Network), http://papers.ssrn.com/sol3/ papers.cfm?abstract_id=2350964 (accessed on 15 May 2014).

École polytechnique fédérale de Lausanne (EPFL) (2012) Cours massifs en ligne en Afrique et dans les futurs pays émergents, Résumé du projet préparé en vue du Sommet de la Francophonie de Kinshasa par le Département fédéral suisse des affaires étrangères et l'EPFL (Lausanne: EPFL).

Emanuel, E.J. (2013) 'Online Education: MOOCs Taken by Educated Few', Nature, 503, p. 342, DOI: $10.1038 / 503342 \mathrm{a}$.

Haggard, S., W. Lawton, A. Katsomitros, T. Gore and T. Inkelaar (2013) The Maturing of the MOOC: Literature Review of Massive Open Online Courses and Other Forms of Online Distance Learning, Report for the UK Department for Business, Innovation and Skills, BIS Research Paper, No. 130, http://www.obhe.ac.uk/documents/down load?id=933 (accessed on 4 February 2014).

Harvard Magazine (2013) 'What Modularity Means for MOOCs', Havard Magazine, 12 May, http://harvardmagazine.com/2013/12/harvard-mit-online-education-viewschanging (accessed on 10 February 2014). 
Illich, I. (1971)Deschooling Society (NewYork:Harper \& Row), http://www.davidtinapple .com/illich/1970_deschooling.htm (accessed on 9 February 2014).

Kelly, R. (2014) 'Inside the First Year Data from MITx and HarvardX', Campus Technology, 27 January, http://campustechnology.com/articles/2014/01/27/insidethe-first-year-data-from-mitx-and-harvardx.aspx (accessed on 12 February 2014).

Kepler (2013) Project description, http://static.squarespace.com/static/5lefe601e4b0 a8f058512075/t/5lf6clf2e4b0d96d01lb07f2/1375126002526/Kepler\%20project\% 20description.pdf (accessed on 16 May 2014).

Koller, D. (2013) 'How Online Education Can Create a "Global Classroom”', CNN, 21 June, http://edition.cnn.com/2013/06/21/business/opinion-koller-educationpetersburg-forum/?hpt=hp_c5 (accessed on 12 May 2014).

Lane, A. (2013) 'The Potential of MOOCs to Widen Access to, and Success in, Higher Education Study', The Open and Flexible Higher Education Conference 2013 (Paris: EADTU), pp. 189-203.

Laurillard, D. (2014) 'Five Myths about MOOCs', Times Higher Education, 16 January, http://www.timeshighereducation.co.uk/comment/opinion/five-myths-aboutmoocs/2010480.article (accessed on 31 January 2014).

Lawton, W., M. Ahmed, T. Angulo, A. Axel-Berg, A. Burrows and A. Katsomitros (2013) Horizon Scanning: What Will Higher Education Look Like in 2020?, Observatory on Borderless Higher Education Research Series, 12, http://www.lfhe.ac.uk/en/news/ index.cfm/horizonscanning (accessed on 4 February 2014).

Lawton, W. and A. Burrows (2013) Is There a Technical Fix for sub-Saharan Universities, Observatory on Borderless Higher Education, http://www.obhe.ac.uk/newsletters/ borderless_report_june_2013/is_there_a_technical_fix_for_subsaharan_universities (accessed 2 February 2014).

Lawton, W. and A. Katsomitros (2012) MOOCs and Disruptive Innovation: The Challenge to HE Business Models, Observatory on Borderless Education, http://www.obhe .ac.uk/documents/download?id=929 (accessed on 10 February 2014).

Liyanagunawardena, T., S. Williams and A. Adams (2013) 'The Impact and Reach of MOOCs: A Developing Countries' Perspective', Elearning Papers (33), pp. 1-8, http://centaur.reading.ac.uk/32452/1/In-depth_33_1.pdf (accessed on 1 February 2014).

Mkandawire, T. (2005) Targeting and Universalism in Poverty Reduction (Geneva: UNRISD).

O'Neil, M. (2013) 'Rwandan Degree Program Aims for a "University in a Box", The Chronicle of Higher Education, 16 September, http://chronicle.com/article/ Rwandan-Degree-Program-Aims/141631/ (accessed on 1 February 2014).

President's Council of Advisors on Science and Technology (PCAST) (2013) Education Technology, Letter to the President on recommendations related to technology in 
higher education, http://www.whitehouse.gov/sites/default/files/microsites/ostp/ PCAST/pcast_edit_dec-2013.pdf (accessed on 10 February 2014).

Samoff, J. and B. Caroll (2003) From Manpower Planning to the Knowledge Era: World Bank Policies on Higher Education in Africa, Forum on Higher Education, Research and Knowledge, Division of Higher Education (Paris: UNESCO).

Stanford, P. (2013) 'University Education: Maturing of the MOOC?', The Telegraph, 2 November, http://www.telegraph.co.uk/education/universityeducation/10414989/ University-education-maturing-of-the-Mooc.html (accessed on 12 February 2014).

UNESCO (2013) Introduction to MOOCs: Avalanche, Illusion or Augmentation? (Paris: UNESCO), http://iite.unesco.org/pics/publications/en/files/3214722.pdf (accessed on 31 January 2014).

Varghese, N.V. (2004) Higher Education in Africa (Paris: UNESCO - IIEP), www.unesco .org/iiep/PDF/pubs/PrivatHEAfr.pdf (accessed on 1 February 2014).

We Are Social (2014) Global Digital Statistics 2014, http://www.slideshare.net/ wearesocialsg/social-digital-mobile-around-the-world-january-2014 (accessed on 4 February 2014).

World Bank (2013) 10 Principles to Consider When Introducing ICTs into Remote, Lowincome Educational Environment (Washington, D.C.: World Bank).

(2010) Financing Higher Education in Africa (Washington, D.C.: World Bank), DOI: 10.1596/978-0-8213-8334-6.

(2008) New Economy Skills for Africa Program-Information and Communication Technologies (Washington, D.C.: World Bank), http://web.worldbank.org/WBSITE/ EXTERNAL/TOPICS/EXTEDUCATION/0,,contentMDK:22335863 menuPK:617610 $\sim$ pagePK:148956 piPK:216618 theSitePK:282386,00.html (accessed on 7 May 2014).

Younous, A. (2012) 'Online Education for Developing Contexts', XRDS: Crossroads, 19(2), pp. 27-29, DOI: 10.1145/2382856.2382868. 